\title{
Une source cadastrale du district de Temnikov (1613/14) : Lecture continue et étude statistique
}

The land register of the district of Temnikov (1613/14) as a possible source: continuous reading and statistical analysis

\section{Elisabeth Teiro}

\section{(2) OpenEdition}

\section{Journals}

Édition électronique

URL : https://journals.openedition.org/emscat/1130

DOI : 10.4000/emscat.1130

ISSN : 2101-0013

Éditeur

Centre d'Etudes Mongoles \& Sibériennes / École Pratique des Hautes Études

Édition imprimée

Date de publication : 1 décembre 2008

Pagination : 45-74

ISBN : 978-2-9518888-4-5

ISSN : 0766-5075

\section{Référence électronique}

Elisabeth Teiro, "Une source cadastrale du district de Temnikov (1613/14) : Lecture continue et étude statistique ", Études mongoles et sibériennes, centrasiatiques et tibétaines [En ligne], 38-39 | 2008, mis en ligne le 17 mars 2009, consulté le 13 juillet 2021. URL : http://journals.openedition.org/emscat/1130 ; DOI : https://doi.org/10.4000/emscat.1130

Ce document a été généré automatiquement le 13 juillet 2021.

(c) Tous droits réservés 


\section{Une source cadastrale du district de Temnikov (1613/14) : Lecture continue et étude statistique}

The land register of the district of Temnikov (1613/14) as a possible source: continuous reading and statistical analysis

Elisabeth Teiro

\section{RÉSUMÉS}

À l'issue du Temps des Troubles fut lancée une description des terres de l'État russe nécessaire au pouvoir nouvellement installé. La dozornaja kniga du district de Temnikov, établie en 1613/14 par Ivan Usov et ses collègues, est une des rares sources cadastrales de ce type qui nous est parvenue. Sa valeur pour l'histoire des cadastres comme pour l'histoire des Tatars est incontestable. L'auteur présente ici les remarques qui se sont imposées à elle lors de la lecture suivie et de l'étude statistique de cette source. Elle aborde notamment les méthodes de compilation du cadastre, les caractéristiques du peuplement et de la population, la question religieuse, le statut de détenteurs de biens-fonds et insiste sur les questions auxquelles ne permet pas de répondre ce document.

By the end of the 'Times of Trouble' (Smutnoe vremja), the Russian state initiated a survey of its lands - a project, which was essential to its newly installed power. The dozornaja kniga of the Temnikov district, which was compiled in $1613 / 14$ by Ivan Usov and his colleagues, constitutes one of the few existing cadastral sources of this kind. Its value for the history of cadastral registers and for the history of the Tatars is indisputable. In this article, the author presents those aspects of the document that impressed her as she read it and made a statistical analysis of 
the data it contains. She examines, among other things, the methods employed in compiling the register, the characteristics of the settlement and the population, the religious question, and the status of landowners. Finally, she reflects on the questions that remain unanswered in the document.

\section{INDEX}

Thèmes : histoire, minorités ethniques

Index géographique : Russie

nomsmotscles Russe, Turc, Tatar

Mots-clés : cadastre, Mordovie, Tatarstan

Keywords : register, Mordovie, Tatarstan

\section{AUTEUR}

\section{ELISABETH TEIRO}

Elisabeth Teiro est docteur en sciences historiques et philologiques et maître de conférences à l'Université Pédagogique Municipale de Moscou (MGPU). Elle s'intéresse en particulier à l'histoire de l'Église russe (XIVe-XIVe siècles) et aux Tatars au service de l'État russe (fin XVIe-début XVIIe). elisabeth.teiro@gmail.fr 